\title{
Evaluation of the physical and chemical parameters of Minas Frescal and Ricotta cheese marketed in Fortaleza, Ceará ${ }^{1}$
}

\author{
Avaliação dos parâmetros físico-químicos de queijos Minas Frescal e Ricota \\ comercializados em Fortaleza Ceará
}

\author{
Ana Paula Colares de Andrade ${ }^{2 *}$, Michelle Fontinele Quirino ${ }^{3}$, Talita Lima e Silva ${ }^{3}$ and Juliane Doering Gasparin \\ Carvalho $^{2}$
}

\begin{abstract}
Cheeses are dairy products prepared from coagulated milk, and which, under Brazilian legislation, can be classified according to their fat and moisture content. Cheeses such as Minas Frescal and Ricotta have a high moisture content and are highly perishable. As such, chemical changes can occur and interfere with the shelf life of these products. In order to evaluate the physical and chemical parameters of Minas Frescal and Ricotta cheeses marketed in Fortaleza, Ceará, 10 samples of the products were evaluated. The variables of weight, temperature, titratable acidity, $\mathrm{pH}$, moisture and fat were measured in triplicate. It was checked that the results conformed to current Brazilian legislation, and it was found that $100 \%$ of the samples had high temperature and high acidity, while the moisture content was below that established by legal standards. Some of the samples of Minas Frescal (40\%) and Ricotta cheese (20\%) had a low dry-extract fat index (DEF). In view of the above, greater control over production is suggested, in order to standardise the composition of the products and comply with legislative parameters, as a way of guaranteeing consumer rights and minimising health risks.
\end{abstract}

Key words: Quality control. Dairy products. Food safety.

\begin{abstract}
RESUMO - Queijos são derivados lácteos elaborados a partir da coagulação do leite, os quais podem ser classificados pela legislação brasileira de acordo com o teor de gordura e umidade. Queijos como o Minas Frescal e a Ricota apresentam grande teor de umidade, sendo muito perecíveis. Desta forma, alterações químicas podem ocorrer e interferir na vida útil desses produtos. Objetivando avaliar os parâmetros físico-químicos dos queijos Minas Frescal e Ricota comercializados em Fortaleza-Ceará foram avaliadas 10 amostras desses produtos. As variáveis peso, temperatura, acidez titulável, $\mathrm{pH}$, umidade e gordura foram mensuradas em triplicata. A conformidade dos resultados obtidos foi verificada na legislação brasileira vigente. Observou-se que $100 \%$ das amostras estavam com a temperatura e acidez elevadas, enquanto o teor de umidade se encontrava abaixo do estabelecido pelos padrões legais. Uma parte das amostras de queijo Minas Frescal (40\%) e de Ricota (20\%) apresentou baixo índice de gordura no extrato seco (GES). Diante do exposto, sugere-se maior controle sobre a produção com intuito de padronizar a composição dos produtos e cumprir os parâmetros da legislação como forma de garantir o direito do consumidor e minimizar os riscos à saúde.
\end{abstract}

Palavras-chave: Controle de qualidade. Produtos lácteos. Segurança dos alimentos.

\footnotetext{
DOI: $10.5935 / 1806-6690.20200022$

*Author for correspondence

Received for publication in 26/08/2018; approved in 12/11/2019

${ }^{1}$ Trabalho de Conclusão de Curso da Segunda Autora, Centro Universitário Estácio do Ceará

${ }^{2}$ Departamento de Engenharia de Alimentos, Universidade Federal do Ceará/UFC, Campus do Pici, Fortaleza-CE, Brasil, ana.colares@hotmail.com (ORCID ID 0000-0003-0554-4376), julianedgc@ gmail.com (ORCID ID 0000-0002-0199-7864)

${ }^{3}$ Curso de Nutrição, Centro Universitário Estácio do Ceará, Campus Via Corpvs, Fortaleza-CE, Brasil, chellefontenele @ hotmail.com (ORCID ID 00000003-2773-5675), talitalima_new@ hotmail.com (ORCID ID 0000-0001-8525-8040)
} 


\section{INTRODUCTION}

Cheese is a dairy product prepared from coagulated milk. It is a product containing many nutrients, and is suitable for use in for diets, due to its high digestibility when compared to other foods (SAGIORATO; PFÜLLER, 2015).

According to the Brazilian Association of Cheese Industries (ABIQ), the domestic production of dairy products under federal inspection (SIF), was around 745 thousand tons between 2000 and 2010. Investment in new technology on the part of the manufacturers, together with a rise in consumer income, has resulted in an increase in the production and consumption of cheese. In addition, the inclusion of cheeses in culinary dishes, to add flavour and nutritional value, generates recipe options that boost the sale of these products (ASSOCIAÇÃO BRASILEIRA DAS INDÚSTRIAS DE QUEJOS, 2011).

In relation to the quality of the various types of cheese, Brazilian legislation classifies them according to their moisture and fat content. For moisture, cheeses are described as very hard, hard, semi-hard and fresh; for lipid content, they are classified as fat, semi-fat, low-fat and skimmed (COSTA, 2012).

Minas Frescal cheese is one of the most-consumed products in the country. It is manufactured through the enzymatic coagulation of milk with rennet and/or other suitable coagulating enzymes, supplemented or not by the action of specific lactic acid bacteria. It is whitish in colour, with a round shape and has a soft, smooth consistency, weighing from 0.3 to $5 \mathrm{~kg}$ (SANTOS; HOFFMANN, 2010). It is considered a semi-fat cheese with a high moisture content, that should be consumed fresh (BRASIL, 1997a). Its aroma is soft and delicate, and slightly acidic, with a $\mathrm{pH}$ greater than 5.0 (DAGOSTIN, 2011). It is important for it to be packed in suitable packaging and kept at temperatures not exceeding $8^{\circ} \mathrm{C}$ (BRASIL, 1997a).

Ricotta, on the other hand, gained prominence in the dairy market for being considered a low-fat cheese by consumers, who use this product in their diets. The raw material used in processing Ricotta is a sweet whey obtained from cheese production in which the milk is enzymatically coagulated. It is usually cylindrical in shape, weighs from 0.3 to $1.0 \mathrm{~kg}$, with a rough surface, a soft, non-pasty friable consistency, closed texture or with a few mechanical openings, and has a white or creamywhite colour (BRASIL, 1997b).

Cheeses such as Minas Frescal and Ricotta have a high moisture content and are highly perishable. The intrinsic characteristics of these products favour microbial growth that can cause everything from a simple alteration in the food to severe illness. To ensure the quality of a food product suitable for consumption, it must be carefully manufactured, stored and distributed (GARCIA et al., 2017; OLIVEIRA et al., 2017; PINTO et al., 2011; RODRIGUES; FERREIRA, 2016).

Considering that, due to the high water content, chemical changes related to storage conditions can occur that may interfere in the shelf life of the product, the aim of this study was to evaluate the physical and chemical parameters of Minas Frescal and Ricotta cheeses marketed in Fortaleza, Ceará.

\section{MATERIAL AND METHODS}

Ten cheese samples were used to carry out this study, consisting of five brands of Minas Frescal cheese and five brands of Ricotta cheese, purchased in supermarkets located in the city of Fortaleza, Ceará. The storage temperature was checked by means of a properly calibrated laser thermometer (Minipa, model MT-330). Samples were collected during March 2018, and the work carried out in the Food Analysis Laboratory of the Estácio Ceará University Centre and in the Dairy Laboratory of the Food Engineering Department at the Federal University of Ceará.

The cheeses were taken to the laboratories in isothermal boxes containing ice, at a temperature of approximately $8^{\circ} \mathrm{C}$. Shortly after, they were weighed on a digital scale (Gehaka, model BK 600) to check the weight. The physical and chemical analysis included: hydrogen potential ( $\mathrm{pH}$ ); titratable acidity (TA), expressed in \% lactic acid; humidity (oven drying) and fat (ASSOCIATION OF OFFICIAL ANALYTICAL CHEMISTS, 1995). All the determinations were made in triplicate.

The $\mathrm{pH}$ was determined using a Digital $\mathrm{pH}$ meter (PHTEK, model PHS-3B), calibrated with a standard buffer solution. Ten grams of each cheese were weighed in a beaker and then diluted with the aid of $100 \mathrm{~mL}$ of water. The contents were stirred with a magnetic stirrer (IKA, MS3 basic) until the particles were uniformly suspended.

To determine the total titratable acidity, five grams of each cheese were transferred to a $125 \mathrm{~mL}$ Erlenmeyer flask and $50 \mathrm{~mL}$ of water was added. Four drops of phenolphthalein solution were then added and titrated with a $0.1 \mathrm{M}$ sodium hydroxide solution until turning pink.

The humidity was determined by direct drying in an oven at $105^{\circ} \mathrm{C}$. A five-gram aliquot of each cheese was weighed in a porcelain capsule which had been previously heated in an oven (Quimis, Q314M123) for three hours and cooled in a desiccator to room temperature. The heating and cooling operations were repeated to constant weight. The humidity was determined using the following equation: 


\section{$100 \times N=$ Moisture or volatile substances at $105^{\circ} \mathrm{C} \% \mathrm{w} / \mathrm{w}$ $P$}

where: $N=$ number of grams of moisture (weight loss in g); $P=$ number of grams of the sample.

The lipid content was determined by the Gerber method, where three grams of each sample were weighed in a butyrometer. Five $\mathrm{ml}$ of water $\left(40{ }^{\circ} \mathrm{C}\right)$ were then added, followed by the slow addition of $10 \mathrm{~mL}$ sulphuric acid, $1 \mathrm{~mL}$ isoamyl alcohol and warm water until the tube was full. The butyrometer was immediately stoppered and shaken. The tube was inverted and placed in a water bath (Biomatica) at $65^{\circ} \mathrm{C}$ for 15 minutes and then transferred to a Gerber centrifuge (model 8BT) where it was centrifuged for 10 minutes at $1.200 \mathrm{rpm}$. The percentage of fat was read directly on the butyrometer scale.

The data obtained were tabulated using the Microsoft Excel 2013 software. The descriptive analysis of the variables was presented as mean values with their respective standard deviations.

\section{RESULTS AND DISCUSSION}

The results for the physical and chemical parameters of the samples of Minas Frescal and Ricota cheeses were compared with the specific legal norms of the Ministry of Agriculture, Livestock and Supply (MAPA) relative to the products under evaluation.

The results showed that at the point of sale the samples of Minas Frescal and Ricota were at an average temperature of 8.1 to $11.0^{\circ} \mathrm{C}$ (Tables 1 and 2) and did not meet current legal standards. The legislation recommends these products being kept at temperatures not exceeding $8{ }^{\circ} \mathrm{C}$ in order to guarantee food safety and increase the shelf life of the cheeses.
Lima and Costa (2013) found that storage at temperatures below $8{ }^{\circ} \mathrm{C}$ is recommended to delay the proliferation of microorganisms, especially psychrotrophic microorganisms, and contributes to the quality of the product.

It was found that the weight of the cheeses varied from 285 to $486 \mathrm{~g}$ and from 325 to $350 \mathrm{~g}$ for Minas Frescal and Ricotta cheese respectively, confirming the standardisation of the products.

The $\mathrm{pH}$ values for Minas Frescal cheese ranged from 5.57 to 6.45 , agreeing with the results found by Carvalho, Viotto and Kuaye (2007), in research that evaluated the quality of 93 samples of Minas Frescal cheese produced by different processing methods.

However, this result differs from that found by Resende (2010), who evaluated 18 samples of artisanal Minas cheese and found that the $\mathrm{pH}$ values ranged from 5.20 to 5.52 , and that these values may be related to the residual presence of lactose in the cheese.

For the Ricotta, the mean $\mathrm{pH}$ values ranged from 4.4 to 6.1. Similar results were found by Carrijo et al. (2011), with values of from 4.7 to 6.2 in fresh Ricotta sold in the city of Niterói. In another study, Lima and Costa (2013) found variations in $\mathrm{pH}$ of between 6.3 to 6.5 , demonstrating the low acidity of the product, which may have been caused by the addition of lactic acid during preparation.

Values for titratable acidity ranged from 0.77 to $1.73 \%$ between the samples of Minas Frescal cheese. A similar result was found by Oliveira et al. (2016), with values for titratable acidity of from 0.67 to $1.77 \%$.

In a study on the shelf life of Minas Frescal cheese, Sangaletti et al. (2009) found that after 21 days storage there was an increase of $0.026 \%$ in the lactic acid content, which suggests a direct correlation with increases

Table 1 - Physical and chemical parameters of samples of Minas Frescal cheese sold in Fortaleza, Ceará

\begin{tabular}{|c|c|c|c|c|c|c|}
\hline \multirow{2}{*}{ Parameter } & \multicolumn{5}{|c|}{ Brand } & \multirow{2}{*}{ Reference limit* } \\
\hline & A & B & $\mathrm{C}$ & $\mathrm{D}$ & $\mathrm{E}$ & \\
\hline Temperature & $8.1^{\circ} \mathrm{C}$ & $11.0^{\circ} \mathrm{C}$ & $10.3^{\circ} \mathrm{C}$ & $9.3^{\circ} \mathrm{C}$ & $8.3^{\circ} \mathrm{C}$ & $<8^{\circ} \mathrm{C}$ \\
\hline Weight & $355.0 \mathrm{~g}$ & $285.0 \mathrm{~g}$ & $440.0 \mathrm{~g}$ & $486.0 \mathrm{~g}$ & $41.02 \mathrm{~g}$ & $0.3-5.0 \mathrm{~kg}$ \\
\hline $\mathrm{pH}$ & $6.26( \pm 0.21)$ & $5.63( \pm 0.79)$ & $6.15( \pm 0.10)$ & $5.57( \pm 0.10)$ & $6.45( \pm 0.16)$ & 5.75 to $6.47(3)$ \\
\hline Acidity & $1.43( \pm 0.67)$ & $1.17( \pm 0.15)$ & $1.17( \pm 0.42)$ & $1.73( \pm 0.06)$ & $0.77( \pm 0.06)$ & $\%$ Lactic Acid 0.10 - 0.68(4) \\
\hline Moisture & $45.68 \%( \pm 1.0)$ & $45.38 \%( \pm 7.25)$ & $42.86 \%( \pm 7.11)$ & $48.05 \%( \pm 6.09)$ & $46.69 \%( \pm 0.99)$ & $46-54.9 \%$ \\
\hline Fat & $15.00 \%( \pm 0.005)$ & $30.00 \%( \pm 0.06)$ & $27.33 \%( \pm 0.03)$ & $22.33 \%( \pm 0.02)$ & $25.33 \%( \pm 0.02)$ & $25.0-44.9 \%$ \\
\hline
\end{tabular}

Mean and \pm standard deviation (SD) of the physical and chemical analysis carried out in triplicate; *Reference limit: (1) Brazil (1996); (2) Brazil (1997); (3) Carvalho, Viotto and Kuaye (2007) as established in Ordinance No 146/96, Ordinance No 352/97 and Ordinance No 53/2013 (MAPA); (4) Ricardo et al (2011) 
Table 2 - Physical and chemical parameters of samples of Ricotta sold in Fortaleza, Ceará

\begin{tabular}{|c|c|c|c|c|c|c|}
\hline \multirow{2}{*}{ Parameter } & \multicolumn{5}{|c|}{ Brand } & \multirow{2}{*}{ Reference limit* } \\
\hline & A & B & $\mathrm{C}$ & $\mathrm{D}$ & E & \\
\hline Temperature & $11.9^{\circ} \mathrm{C}$ & $9.1^{\circ} \mathrm{C}$ & $9.8^{\circ} \mathrm{C}$ & $8.8^{\circ} \mathrm{C}$ & $9.3^{\circ} \mathrm{C}$ & $<8^{\circ} \mathrm{C}$ \\
\hline Weight & $325 \mathrm{~g}$ & $350 \mathrm{~g}$ & $340 \mathrm{~g}$ & $335 \mathrm{~g}$ & $345 \mathrm{~g}$ & $0.3-1 \mathrm{~kg}$ \\
\hline $\mathrm{pH}$ & $5.20( \pm 0.72)$ & $4.44( \pm 0.07)$ & $6.13( \pm 0.02)$ & $4.86( \pm 0.14)$ & $4.93( \pm 0.05)$ & 4.4 a $6.1(3)$ \\
\hline Acidity & $1.17( \pm 0.15)$ & $2.57( \pm 0.12)$ & $0.67( \pm 0.06)$ & $2.77( \pm 0.40)$ & $1.80( \pm 0.36)$ & $\%$ Lactic Acid $0.08-0.14$ \\
\hline Moisture & $43.40 \%( \pm 1.78)$ & $38.58 \%( \pm 5.58)$ & $49.81 \%( \pm 5.88)$ & $46.16 \%( \pm 0.98)$ & $45.46 \%( \pm 1.21)$ & Very High Moisture > 55\% \\
\hline Fat & $18.17 \%( \pm 0.04)$ & $5 \%( \pm 0)$ & $11.17 \%( \pm 1.76)$ & $22.17 \%( \pm 3.75)$ & $22.5 \%( \pm 3.46)$ & Low-fat $10-24.9 \%$ \\
\hline
\end{tabular}

Mean and \pm standard deviation (SD) of the physical and chemical analysis carried out in triplicate *Reference limit: (1) Brazil (1996); (2) Brazil (1997a); Brazil (2013); Carrijo et al. (2011)

in the population of mesophilic and psychrotrophic microorganisms, and especially lactic acid bacteria, which are the main agents in transforming lactose into lactic acid. However, excessive acidity can impair the sensory aspects of fresh cheeses such as Minas Frescal and Ricotta, as it characterises the acid flavour, thereby wrongly characterising the products.

The minimum value for acidity obtained in the Ricotta cheeses was $0.7 \%$; the highest value for this parameter was $2.8 \%$. A similar result was found by Camini et al. (2014), with values of between 0.9 and $2.1 \%$ when evaluating the physical and chemical characteristics of Ricotta chees marketed in the Taquari River Valley.

The moisture content seen for the samples under evaluation, of from 42.86 to $48.05 \%$, classifies Minas Frescal cheese (Table 1) as a 'high moisture' cheese, generally recognised to be a soft or smooth cheese, with a humidity of between 46.0 and $54.9 \%$, as per Ordinance No 146/1996/MAPA (BRASIL, 1996).

The mean values for moisture content in the Ricotta samples, of between 38.58 and $49.81 \%$, classify them as medium and high-moisture cheeses, not meeting the standard (>55\%) established by legislation (BRASIL, 1996). This result differs from those found by Santos (2010), who obtained a mean value for humidity of $63.75 \%$ when evaluating samples of Ricotta from a small dairy located in the municipality of São José do Rio Preto, São Paulo.

Camini et al. (2014) saw a moisture content of between 55.98 and $76.42 \%$ in samples of Ricotta marketed in the Taquari River Valley and found that this variation may be related to draining after the cheese is pressed, which causes heterogeneous dehydration of the samples. The values showed a greater range of variation compared to those found in this study, reflecting the need to establish specific standards for moisture content, since the legislation does not specify a maximum limit, which can affect product standardisation in the market. In addition, many producers may reduce the nutritional quality of the cheese, producing cheeses with high levels of moisture in order to generate profit.

Three of the samples of Minas Frescal cheese that were analysed can be classified as semi-fat cheeses, since they had a mean value for fat content of from 25.33 to $30 \%$. However, two samples showed mean values of 15.00 and $22.33 \%$ (DEF), falling within the classification of a low-fat cheese. This result is similar to that found by Silva and Ferreira (2010), who classified 75\% (21/24) of the samples evaluated as semi-fat cheese. However, in the same study, two samples were classified as fat cheese, since the fat content in the dry extract was 45 and $47 \%$ respectively.

Of the five Ricotta brands under analysis, four had a percentage GES of between 11.2 and $22.2 \%$, and were classified as low-fat cheese. In another study, Silva and Ferreira (2009) found a variation of from 6.4 to 20\%, in relation to fat content for the Ricotta samples under evaluation.

Determining the fat content of cheeses such as Ricotta should be considered relevant, since the product is classified as a low-fat food, and is generally used by people with some type of dietary restriction.

Characterising the physical and chemical parameters of food, especially cheeses, should be considered very important, since quality is associated with the actual values found and with comparison with the values established by current legislation. In addition, carrying out routine analyses, requested by the owners and inspection authorities, makes it possible to monitor and improve the quality of the products.

\section{CONCLUSIONS}

1. The analysis showed that most of the samples fell outside the criteria determined by legislation. The high 
acidity may be related to the storage temperature of the products under evaluation;

2. Samples of Minas Frescal and Ricotta cheese also showed a low dry-extract fat index (DEF), which demonstrates a variation in quality. As such, there is a need for greater control of the production process, especially in relation to standardising the composition of the product, to complying with legislation, to increasing profits and to guaranteeing consumer rights;

3. As such, monitoring is suggested, with more analysis carried out on the part of the manufacturers and supervisory bodies, with the aim of improving the quality of the product and safety of the consumer.

\section{REFERENCES}

ASSOCIAÇÃO BRASILEIRA DAS INDÚSTRIAS DE QUEIJOS. Avanços e perspectivas da indústria brasileira de queijos. Revista Mundo do Leite, 2011. Disponível em: http:// www.abiq.com.br/imprensa_ler.asp? codigo $=1003 \&$ codigo_ categoria $=2 \&$ codigo_subcategoria $=17$. Acesso em: 26 maio 2016.

ASSOCIATION OF OFFICIAL ANALYTICAL CHEMISTS. Official methods of Analysis. 15 th ed. Washington, 1995.

BRASIL. Ministério da Agricultura, Pecuária e Abastecimento. Portaria $\mathrm{n}^{\circ} 146$, de 7 de março de 1996. Regulamento técnico de identidade e qualidade dos queijos. Diário Oficial da União, Brasília, DF, 11 mar. 1996. Seção 1, p. 3977.

BRASIL. Ministério da Agricultura, Pecuária e Abastecimento. Portaria $\mathrm{n}^{\circ}$ 53, de 10 de abril de 2013. Regulamento Técnico de Identidade e Qualidade de Soro de Leite. Diário Oficial da União, Brasília, DF, 2013.

BRASIL. Ministério da Agricultura, Pecuária e Abastecimento. Portaria $\mathrm{n}^{\circ} 352$ de 4 de setembro de 1997. Aprova o regulamento técnico para fixação de identidade e qualidade de queijo Minas Frescal. Diário Oficial da União, Brasília, DF, 8 set. 1997a. Seção 1, p. 19684.

BRASIL. Ministério da Agricultura, Pecuária e Abastecimento. Regulamento da inspeção industrial e sanitária de produtos de origem animal (RIISPOA). Decreto $\mathrm{n}^{\circ}$ 30691-52, de 29 de março de 1952, Art. 610. Diário Oficial da União, Brasília, DF, 1997b.

CAMINI, A. et al. Características físico-químicas de ricotas comercializadas no Vale do Taquari. Revista Destaques Acadêmicos, v. 6, n. 4, p. 96-100, 2014.

CARRIJO, K. F. et al. Avaliação da qualidade microbiológica e físico-química de ricotas frescas comercializadas no município de Niterói, Rio de Janeiro, Brasil. Veterinária Notícias, v. 17, n. 2, p. 97-110, 2011.

CARVALHO, J. D. G.; VIOTTO, W. H.; KUAYE, A. Y. The quality of minas frescal cheese produced by different technological processes. Food Control, v. 18, p. 262-267, 2007.
COSTA, W. N. Análise físico-química de queijo minas padrão comercializados em feiras livres na cidade de Goiânia. 30 f. 2012. Trabalho de Conclusão de Curso (Bacharelado em Química Industrial) - UnUCET, Universidade Estadual de Goiás, Anápolis, 2012. 30 p.

DAGOSTIN, J. L. A. Avaliação de atributos microbiológicos e físico-químicos de queijo minas frescal elaborado a partir de leite carbonato. 2011. 79 f. Dissertação (Mestrado em Tecnologia de Alimentos) - Setor de Tecnologia, Universidade Federal do Paraná, Curitiba, 2011.

GARCIA, E. P. et al. Qualidade microbiológica de queijos minas frescal e ricota comercializados na Região Metropolitana de Campinas-SP. Higiene Alimentar, v. 31, n. 264/265, 2017.

INSTITUTO ADOLFO LUTZ. Normas analíticas do Instituto Adolfo Lutz: métodos químicos e físicos para análise de alimentos. 3. ed. São Paulo: IMESP, 2008. v. 1.

LIMA, M. F.; COSTA, R. R. G. F. Análises físico-químicas e microbiológicas de ricota fresca em laticínio no Sudoeste Goiano. Revista de Biotecnologia e Ciência, v. 2, n. 2, p. 7588, 2013.

OLIVEIRA, A. M. et al. Condições higiênico-sanitárias da produção de queijos tipo mussarela e minas frescal comercializados no norte do Paraná. Revista do Instituto de Laticínios Cândido Tostes, v. 72, n. 1, p. 40-47, 2017.

OLIVEIRA, K. A. M. et al. Avaliação físico-química, microbiológica e sensorial de queijo minas frescal de leite de cabra desenvolvido por acidificação direta e fermentação lática. Revista do Instituto de Laticínios Cândido Tostes, v. 71, n. 3, p. 166-178, 2016.

PINTO, F. G. S. et al. Qualidade microbiológica de queijo minas frescal comercializado no município de Santa Helena, PR, Brasil. Arquivos do Instituto Biológico, v. 78, n. 2, p. 191-198, 2011.

RESENDE, M. F. Queijo minas artesanal da Serra da Canastra: influência da altitude e do nível de cadastramento das queijarias nas características físico-químicas e microbiológicas. Dissertação (Mestrado em Ciência Animal) - Escola de Veterinária, Universidade Federal de Minas Gerais, Belo Horizonte, 2010.

RICARDO, N. R. et al. Análise físico-química de queijos minas frescal artesanais e industrializados comercializados em Londrina-PR. Revista Brasileira de Pesquisa em Alimentos, v. 2, n. 2, p. 89-95, 2011.

RODRIGUES, C. R. F; FERREIRA, L. C. Avaliação da qualidade microbiológica de queijo minas padrão produzido no município de Januária - MG. Caderno de Ciências Agrárias, v. 8, n. 1, p. 57-61, 2016.

SAGIORATO, E.; PFÜLLER, E. E. Análise do processamento do leite para produção de queijo colonial na agroindústria de laticínios Sagiorato Sananduva/RS. Ramvi, Getúlio Vargas, v. 2, n. 4, 2015.

SANGALETTI, N. et al. Estudo da vida útil de queijo minas. Ciência e Tecnologia de Alimentos, v. 29, n. 2, p. 262-269, 2009. 
SANTOS, A. S. Queijo minas artesanal da microrregião do Serro-MG: efeito da sazonalidade sobre a microbiota do leite cru e comportamento microbiológico durante a maturação. 2010. 67 f. Dissertação (Pós-Graduação em Produção Animal) Faculdade de Ciências Agrárias, Universidade Federal dos Vales do Jequitinhonha e Mucuri, Diamantina, Minas Gerais, 2010.

SANTOS, V. A. Q.; HOFFMANN, F. L. Evolução da microbiota contaminante em linha de processamento de queijos minas frescal e ricota. Revista Instituto Adolfo Lutz, v. 69 , n. 1 , p. $38-46,2010$.
SILVA, L. F. M; FERREIRA, K. S. Avaliação de rotulagem nutricional, composição química e valor energético de queijo minas frescal, queijo minas frescal "light" e ricota. Revista Alimentos e Nutrição Araraquara, v. 21, n. 3, p. 437-441, 2010 .

SILVA, L. F. M.; FERREIRA, K. S. Composição química e valor energético de queijo minas frescal e ricota. Trabalho de Iniciação Científica. Universidade Estadual do Norte Fluminense Darcy Ribeiro, Campos dos Goytacazes, Rio de Janeiro, 2009. 